Meta

Journal des traducteurs

Translators' Journal

\title{
ANGelelli, Claudia V., ed. (2014): The Sociological Turn in \\ Translation and Interpreting Studies. Amsterdam/Philadelphia: John Benjamins, 140 p.
}

\section{Esmaeil Kalantari}

Volume 61, numéro 3, décembre 2016

URI : https://id.erudit.org/iderudit/1039233ar

DOI : https://doi.org/10.7202/1039233ar

Aller au sommaire du numéro

Éditeur(s)

Les Presses de l’Université de Montréal

ISSN

0026-0452 (imprimé)

1492-1421 (numérique)

Découvrir la revue

Citer ce compte rendu

Kalantari, E. (2016). Compte rendu de [ANGELELLI, Claudia V., ed. (2014): The

Sociological Turn in Translation and Interpreting Studies.

Amsterdam/Philadelphia: John Benjamins, 140 p.] Meta, 61(3), 742-745.

https://doi.org/10.7202/1039233ar d'utilisation que vous pouvez consulter en ligne.

https://apropos.erudit.org/fr/usagers/politique-dutilisation/ 
de un desliz, basta con leer el resto del artículo para borrar cualquier sospecha de etnocentrismo. El artículo de Vega Cernuda, por el contrario, abunda en expresiones ideológicamente cargadas que denotan un rotundo rechazo a la leyenda negra asociada a los períodos de conquista y colonización españolas.

No se pretende en esta reseña hacer eco de esta leyenda negra, cuya exactitud histórica ha sido puesta en duda innumerables veces, sin embargo, tampoco se quiere aquí tomar el derrotero opuesto y caer en la leyenda rosa, que en muchos momentos salta a la vista en el artículo de Vega Cernuda. Si bien, tal como lo plantea el autor, el rol crucial desempeñado por los franciscanos en la conservación de testimonios de algunas lenguas indígenas es innegable, no se puede obviar que fueron muchas veces los mismos frailes quienes destruyeron los documentos, como dejó consignado fray Diego de Landa en su obra del siglo XVII: «Hallámosles gran número de libros de estas sus letras, y porque no tenían cosa en que no hubiese superstición y falsedades del demonio, se los quemamos todos, lo cual sentían a maravilla y les daba pena» (De Landa 1566/1992: 148; Pomerleau 2012: 263). La postura etnocéntrica de Vega Cernuda se evidencia también en su escritura de ciertos topónimos, Méjico y Tezcoco, a pesar de que los habitantes del país centroamericano utilicen otra grafía, y en su denuncia de un «relativismo cultural» que, según él, convierte en intocables ciertas prácticas no occidentales.

Retomaremos también brevemente el artículo de Hugo Marquant, quien le atribuye a la terminología un carácter marcadamente onomasiológico, al que opone lo que él llama terminología diacrónica. La corriente diacrónica, como lo indica su nombre, implica un estudio de la evolución de los términos, los conceptos o las lenguas de especialidad en una ventana temporal (Dury et Picton 2009). Una investigación terminológica con textos antiguos no se inscribe en la corriente diacrónica si no se tiene en cuenta una progresión cronológica. Si Marquant parte del término «quietud» (cuya escogencia no está lo suficientemente justificada) y analiza los conceptos y metáforas conceptuales que de este se derivan, podemos afirmar que adopta una perspectiva sincrónica para estudiar un texto antiguo, pero al no haber un análisis de la evolución del término (o del concepto asociado a este) no se puede hablar en modo alguno de diacronía. Además, el autor no expone con suficiente detalle ciertos aspectos metodológicos, por ejemplo la manera como fueron extraídos los términos. Finalmente, la consulta de la bibliografía no permite saber a qué enfoque terminológico se adscribe el autor, ya que no cita ningún trabajo de esta disciplina.
Como se puede apreciar en nuestras sinopsis de los artículos contenidos en Los franciscanos y el contacto de lenguas y culturas, los estudios sobre la labor de estos frailes son tan variados y ricos como la historia de la O.F.M. La importancia de la labor de esta orden y de su presencia diseminada por el mundo es innegable en la actualidad e indudablemente se debe considerar el importante papel que ha desempeñado en la historia desde el momento mismo de su fundación. No es necesario entonces insistir sobre la importancia de publicaciones como esta, que encierra, sin duda, un gran interés para los estudiosos de la historia de la traducción.

Malka Irina Acosta Padilla Université de Montréal, Montreal, Canadá

\section{REFERENCIAS}

Universidad de VAlladolid (s.d.): Catalogación y estudio de las traducciones de los franciscanos españoles. Soria: Facultad de Traducción e Interpretación, Universidad de Valladolid. Consultado el 12 de diciembre de 2016,

$<$ http://www.traduccion-franciscanos.uva.es/ praga-pub.php $>$.

De LANDA, Diego (1566/1992): Relación de las cosas de Yucatán. In: Miguel Rivera Dorado, ed. Madrid: Información y Revistas.

Dury, Pascaline y Picton, Aurélie (2008): Terminologie et diachronie: vers une réconciliation théorique et méthodologique? Revue française de linguistique appliquée. 2(14):31-41.

Pomerleau, Marc (2012): La traducción del Popol Vuh y el paratexto: El caso del prólogo de Brasseur de Bourbourg. In: Francisco LAFARGA y Luis Pegenaute, eds. Aspectos de la historia de la traducción en Hispanoamérica: autores, traducciones y traductores. Vigo: Academia del Hispanismo, 263-272.

Angelelli, Claudia V., ed. (2014): The Sociological Turn in Translation and Interpreting Studies. Amsterdam/Philadelphia: John Benjamins, 140 p.

In recent years, the sociological turn in translation studies has yielded a broader view of translation as a social activity and of translators as socialized individuals. So far, translation scholars (for example, Tyulenev 2014; Buzelin 2005; Inghilleri 2005a; among others) have pertained various sociological theories, such as habitus and field, to the study of translation, constructing theoretical and methodological bases for investigating translation from a sociological perspective. However, not many attempts have been made to bridge the gap between sociological theories and empirical translation research. In this context, The Sociological Turn in Translation and Interpreting Studies moves 
away from mere theoretical discussions, examining translation sociologically through different case studies.

The book comprises an editorial introduction and seven papers previously published in the special issue of Translation and Interpreting Studies by John Benjamins (2012). The editor of the volume is Claudia V. Angelelli, from Heriot-Watt University in Edinburgh (Scotland), who is known for her research in the fields of translation and interpreting studies, sociolinguistics, and applied linguistics (see Angelelli 2004, to cite a work on interpreting studies).

One of the achievements of the present volume is that it brings together concrete instances of sociologically-informed translation research. Thanks to the papers by Ben-Ari, Osman, and Song which draw on Bourdieu's sociological theories to combine textual analysis with social analysis, the readers can gain an insight as to how sociological theories can be applied to different translation case studies.

In this book, however, there is room for improvement in the content of three chapters namely, the editorial introduction and the chapters allocated to Caliendo's and Mason and Ren's papers. The editorial introduction largely consists of a summary of the papers. In fact, the editor could have better contributed to this volume by providing more information, for example, on the aims and objectives of the book and on how it is situated in and contributes to the literature on the sociology of translation.

As for Caliendo's and by Mason and Ren's contributions, although these studies are carried out on the basis of well-established methodologies, bringing them under the title of sociological turn is debateable, as it is not clear how they adopt sociologically-oriented methods in approaching the topics in question. In her paper on the role of translation in identity construction, Caliendo asserts that she "embraces the concept of translation as a socially-driven process" (p. 75); however, this theoretical framework has not adequately informed her research method. Caliendo identifies the translation strategies which make the source and target texts different in terms of identity formation, but this finding is not accompanied by any analysis of the recipient society or of the translator's 'social trajectory' (Wolf 2007). To investigate identity issues in translation from a sociological outlook more efficiently, the author could have made some assumptions, for instance, as to the relevance of the identified translation strategies to the social dynamics governing the process of translation.

Also, in Mason and Ren's paper on the question of interpreters' power in face-to-face interactions, the authors state that they use analytical insights such as networks of relations and voice to "complement the field and habitus frameworks" (p. 124) used in sociologically-oriented studies of interpreting (for example, Inghilleri 2005b). They do not, however, convincingly explain how their research may have such a function. Moreover, it is not clear how this research may epitomize a sociological turn in interpreting studies. With such analytical tools adopted by the authors, the analyses of various interpreting events in this paper go no further than showing how interpreters exercise their power by adopting various strategies. In general, Mason and Ren's research can be said to be conducted much similarly to the way other studies (for example, Davidson 2001) probe the power of interpreters in constructing a communicative event - the studies which yield interesting results, while adopting no sociological approach.

In the first paper, "The sociology of translation and its 'activist turn'," Michaela Wolf mainly elaborates on the concept of translatorial habitus and examines the limitations and the potential of studying translation from a sociological perspective. The author refers to the interactional nature of the relationship between translation and society and argues that "translatorial habitus not only results from social practice but can also create values and produce knowledge related to action" (p. 13). Furthermore, while translation scholars have focused on Bourdieu's field theory or theory of symbolic goods, Wolf suggests reading Bourdieu's politically-oriented texts from a translatorial perspective, as they can offer useful sociological concepts to the study of translation. In this respect, the author draws on Bourdieu's discussion on political habitus and argues for the relevance of this concept to translation research. From the perspective of translation studies, political habitus can be defined by discussing "the conditions under which a politically oriented translation activity - which ultimately would imply an activist stance - can take place" (p. 15). The significance of this paper is that it contributes to the theoretical discussions on the sociology of translation particularly by associating the translatorial habitus with political and activist concepts.

Following Wolf's theoretical discussion on the notion of translatorial habitus, Nitsa Ben-Ari's paper, "Political dissidents as translators, editors, and publishers," investigates the relationship between the socio-political ideology of the Israeli political dissidents and their professional behaviour. After the triumph of the Socialist Zionist camp in the struggle over the character of the new Israeli nation during World War II, the Revisionists were barred from holding public office and thus many of them became translators, editors, and publishers in the private book industry. These 
people shared the same habitus (that is, a dissident habitus) which can be traced in their professional behaviour. For instance, they did not select themes which revolved around Socialist values for translation. In spite of this relationship between the habitus of the Revisionists and their professional behaviour, the author questions Bourdieu's habitus theory in this paper based on two main reasons. The results of the interviews conducted with the Revisionists - or people who were closely in contact with them - show that (I) there was no factor in the personal background of these people to prepare them for such an occupation, and also (II) there was a lack of homogeneity in the dissident camp regarding political and ideological tendencies. In fact, the Revisionists' "so-called shared habitus was far from homogeneous and its characteristics were shared with many [...] fields" (p. 38). It is also maintained that Bourdieu's field theory does not adequately apply to this study because there is no definable field in this particular case.

Unlike Ben-Ari who problematizes the application of Bourdieu's habitus and field theories to the study of translation, Ghada Osman clearly describes the interplay between habitus and field in a translation context. "The sheikh of the translators: The translation methodology of Hunayn ibn Ishaq" is a historical example of how the translator's habitus "structures field in question and, in turn, is structured by it" (p. 44). Hunayn ibn Ishaq, a master of Syriac, Persian, Greek, and Arabic, is a well-known scholar in the era of the Islamic Golden Age who contributed to various scientific fields, such as medicine, philosophy, astronomy, etc., not only via original writing but also through translation. The paper relates Hunayn's translation methodology, as one of the earliest discussions on the methodology of translation, to the sociolinguistic situation of the Muslim Empire particularly in the ninth century. In that period, Arabic was the official language of government and also the lingua franca for the population of the Muslim Empire, while its nomenclature was inadequate as compared with Syriac, Greek, and Persian. Under this sociolinguistic condition, one of the Hunayn's translation considerations was expanding the Arabic lexicon through Arabicization. The paper also relates other Hunayn's translation methods, such as annotated translation, to the sociolinguistic realities of the time.

Another significant sociological concept introduced by Bourdieu is that of capital which, in comparison with the notions of habitus and field, has received perhaps a less amount of attention in the sociology of translation. "The Art of War in retranslating Sun Tzu: Using cultural capital to outmatch the competition" is a case study which applies cultural capital, as one of the forms of capital, to the study of translation. In this paper, Zhongwei Song explores how the two American translators, Griffith and Gagliardi, use their cultural capital in retranslating the classical Chinese text The Art of War ( $6^{\text {th }}$ century BC). The author analyzes the strategies adopted by the two translators and shows how Gagliardi challenges Griffith's translation. For instance, whereas Griffith adopts an encyclopedic approach by adding a lot of information to the text in order to increase its cultural capital, Gagliardi simplifies his translation and produces a more natural English text. According to Bourdieu, cultural reproducers' struggles over cultural capital are apparently about "defending ideas and satisfying tastes, but they are also about how to control cultural capital and how to eventually convert it into economic capital" (p. 57). In this relation, Song concludes that Gagliardi "has moved [The Art of War] from the realm of high and serious culture into that of low and popular culture" (p. 69) in order to find more readers and successfully convert cultural capital into economic capital. This paper is quite successful in approaching the act of retranslation from a sociological perspective and ultimately presenting it as a social practice.

"Italy's other Mafia: A journey into crosscultural translation" is a case study on the role of translation in identity formation. In this paper, Giuditta Caliendo investigates how the identity of Camorra, an Italian crime organization, is constructed through translation. A contrastive analysis of the English and Italian versions of the non-fiction novel Gomorrah by Roberto Saviano $(2006)^{1}$ brings forth a number of micro-structure translation shifts relevant to the culture-bound elements, intertextual references, and specialized terminology. These translation shifts lead to a difference in the way the source and translated texts offer an image of Camorra. For instance, the translation of the military title "generalesse" (female generals) as "Saxon genitive" (generals' wives) weakens the power and authority of Camorra female leaders in the English version. The author considers the identified translation shifts as results of generalization, omission, and domestication strategies which all together move the English text's function away from the informative function of the source text - that is, informing the readers of the identity of Camorra.

While most of the papers discussed so far concentrate on the process of translation as a social activity, in Helle V. Dam and Karen Korning Zethsen's paper the focus is shifted toward translation as a profession. "Translators in international organizations: A special breed of high-status professionals? Danish EU translators as a case in point" is an empirical study on the occupational status of translators, as a social and professional group. 
The target group of this case study consists of 63 Danish staff translators working in the European Union and 113 Danish staff translators working in the national market. The opinions of the two groups regarding their job status as translators are investigated and compared by means of questionnaires. The questions of the survey are about four major parameters of occupational prestige, including remuneration, education/expertise, power/ influence, and (physical) visibility. On contrary to the initial hypothesis of the authors, the quantitative analysis of the questionnaires shows that the EU translators do not enjoy a higher job prestige, in comparison with the national-market translators. This conclusion is particularly based on the degree of the visibility of the two groups of translators in their workplace. Whereas $41 \%$ of the nationalmarket translators state that their office is close to the center of policy-making, this is the case for only $13 \%$ of the EU translators.

In the last paper, "Power in face-to-face interpreting events," Ian Mason and Wen Ren call into question the traditional view of interpreters as transparent, invisible, neutral, and passive agents in the communication process. They argue that interpreters can be powerful figures because of their "bilingual and bicultural expertise" (p. 115). As an analytical tool, the authors use Michel Foucault's concept of power and define it as "a kind of strategy, disposition, maneuver, tactic, or technique functioning in a network of relations" (p. 115). Several cases of real-life interpreting events are analyzed to show how the interpreters apply their power through verbal and non-verbal strategies. For instance, in an interview between an English immigration officer and an immigrant who has been arrested for working illegally in the UK, the interpreter tries to "empower the institutionally powerless immigrant" (p. 126) by adding some questions to the officer's original question. In this case, the officer asks the immigrant "did you look around for a job in Poland?" and the interpreter translates it as "Did you look for work? You looked for work and there wasn't any?" The immigrant's answer to this question is "Yes," but the original question asked by the officer might promote the answer "No," which would imply that the immigrant is disinclined to work. Mason and Ren conclude that the findings of their research together with those of similar studies (for example, Bolden 2000) show that the exercise of power by interpreters in face-to-face interactions is a general phenomenon.

As a whole, this volume is an asset for all students and researchers interested in the study of translation from a sociological perspective, since it presents the sociology of translation as a turn not only in the way translation is conceived, but also in the way translation is empirically studied.
Moreover, it reveals how sociological theories have opened up new horizons to the study of translation, and in turn how translation studies may bring forth questions (see Ben-Ari's paper in this volume) in sociology - a feature which could also make the present volume interesting for researchers in the sociology field.

ESMAEIL KaLANTARI Université de Montréal, Montreal, Canada

\section{NOTE}

1. The original title is spelled "Gomorra": Saviano, Roberto (2006): Gomorra. Viaggio nell'impero economico e nel sogno di dominio della camorra. Milan: Mondatori.

\section{REFERENCES}

Angelelli, Claudia V. (2004): Medical interpreting and cross-cultural communication. Cambridge: Cambridge University Press.

Angelelli, Claudia V., ed. (2012): Translation and Interpreting Studies. 7(2). Amsterdam/Philadelphia: John Benjamins.

Bolden, Galina B. (2000): Toward understanding practices of medical interpreting: Interpreters' involvement in history taking. Discourse studies. 2(4):387-419.

Buzelin, Hélène (2005): Unexpected allies: How Latour's network theory could complement Bourdieusian analyses in translation studies. The Translator. 11(2):193-218.

DAVIDSON, Brad (2001): Questions in cross-linguistic medical encounters: The role of the hospital interpreter. Anthropological Quarterly. 74(4): 170-178.

INGHILLERI, Moira (2005a): The Sociology of Bourdieu and the Construction of the 'Object' in Translation and Interpreting Studies. The Translator. 11(2):125-145.

Inghilleri, Moira (2005b): Mediating zones of uncertainty: Interpreter agency, the interpreting habitus and political asylum adjudication. The Translator. 11(1):69-85.

Tyulenev, Sergey (2014): Translation and Society: An Introduction. London: Routledge.

Wolf, Michaela (2007): The emergence of a sociology of translation. In: Michaela Wolf and Alexandra Fukari eds. Constructing a Sociology of Translation. Amsterdam: John Benjamins, 1-36.

Castro Ramírez, Nayelli, ed. (2013): Traducción, identidad y nacionalismo en Latinoamérica. México: Bonilla Artigas Editores, 286 p.

Aunque publicada en 2013, esta obra colectiva, desde una perspectiva sociológica (Pym; Delisle), se engloba en los estudios de historia de la traducción de tan renovado interés para los especialistas 